\title{
Growth performance of starter broiler chickens fed processed African yam bean meal as protein source in place of soyabean meal
}

Anyaegbu, B. C., *Onunkwo, D. N., Ezike, J. C., Ogbonna, A. C. and Amanze, L. College of Animal Science and Animal Production,

Michael Okpara University of Agriculture, Umudike, Abia State, Nigeria

*Corresponding author:donunkwol@gmail.com;+2348033388622

\section{Abstract}

Protein source like soyabean meal is expensive and constitutes about 15-30\% of poultry and pig diets. Thus, the study was carried out to determine the growth performance of starter broiler chickens fed processed African yam bean meal as protein source in place of soyabean meal in their diets. The processed African yam bean meal (AYBM) was used to replace soyabean meal at various levels to determine the best level that would give optimal performance in starter broilers. The African yam bean seeds were procured at Ndioro market in Abia state and were sorted to remove stones and dirt by sieving. The seeds were soaked in water for 24 hours in large vats and then, the water was removed and the seeds were air dried for 3 days. The seeds were then toasted for 35 minutes in a frying pan, milled using hammer mill to obtain processed African yam bean meal, and then stored in bags until used. The proximate composition of processed African yam bean meal showed that it contained $8.29 \%$ moisture, $91.71 \%$ dry matter, $3.40 \%$ ash, $21.12 \%$ crude protein, $5.0 \%$ ether extract, $5.73 \%$ crude fibre and $56.46 \%$ nitrogen free extract. In the starter feeding trial, the processed African yam bean was used to replace soyabean meal at levels of 0, 10, 15, 20 and 25\% respectively in the control diet. Each starter diet was fed to a group of 30 broiler chicks for 4 weeks using completely randomized design. Each treatment was divided into 3 replicates of 10 broiler chicks each. The broiler chicks were kept in pens in deep litter and given feed and water ad libitum. Parameters measured include; initial body weight, final body weight, body weight gain, feed intake, feed conversion ratio and cost of production. In the starter broiler feeding trial, the group on 10\% processed AYBM compared favourably with the control $(P>0.05)$ in terms of feed intake, feed conversion ratio and body weight gain. Cost of production per $\mathrm{kg}$ (was lowest for diet 2 (N463.38) against N471.63 for those on control diet. The result of the trial has shown that processed African Yam bean meal can be used to replace soyabean meal in the diet at 10\% for optimum performance of starter broilers without affecting the body weight gain, feed intake and feed conversion ratio.

Keywords: Starter broiler chickens, processed African yam bean meal, soyabean meal

\section{Introduction}

One third of humanity suffers from quantitative malnutrition according to Food and Agricultural Organization (FAO, 1982). Statistics has shown that the average daily intake of animal protein stands at about $6.3 \mathrm{~g}$ as against $35 \mathrm{~g} / \mathrm{caput} / \mathrm{day}$ recommended by Food and Agricultural Organization for the maintenance of the health of the population (Aduku and Olukosi, 1990, and Oyenuga, 1997). The cost of feed has invariably raised the cost of animal production and hence the selling price of animal products such as eggs, pork and meat. This has worsened the low animal protein intake by Nigerians. Adejinmi et al. (2000) reported the rising cost of feed resources in livestock production as a serious impediment to meeting the demand for animal protein particularly in developing countries. The high cost of feed materials is as a result of the increasing competition for grains between man, livestock and industries. The high cost of feed can be reduced by compounding of feed in a way that all required nutrients 


\section{Growth performance of starter broiler chickens}

should come from cheap alternative energy and protein sources (Onyimonyi and Okeke, 2005). Therefore, the discovery and replacing of some feedstuffs will help to reduce the cost of feed and in turn the cost of animal production.

African yam bean seeds (sphenostylis stenocarpa) has been successfully applied in weaner rabbit diets as a substitute for soyabean meal at $10 \%$ inclusion (Akinmutimi et al., 2006). In Nile Tilapia, fingerlings, African yam bean seed meal was used at 15 to $60 \%$ of the dietary protein to substitute for full fat soyabeans (Alegbeye et al., 2002).

African yam bean is a perennial climbing bush, 1-3m high generally grown as an annual. Its leaves are trifoliate with oral leaflets $(2.7$ to $13 \mathrm{~cm}$ long and 0.2 to $5.5 \mathrm{~cm}$ broad). It is cultivated for its edible tubers, which look like elongated sweet potatoes, and for its seed which are contained in hard and tough $20-30 \mathrm{~cm}$ pods. It is mainly used as food but can be used to feed animals. African yam bean (Sphenostylis stenocarpa) is a native to tropical west and central Africa. It is cultivated in Southern and Eastern African. It thrives on deep, loose sandy and loamy soil with good organic matter content and drainage. It grows better in regions where annual rainfall ranges between $800-1400 \mathrm{~mm}$ between $19-27^{\circ} \mathrm{C}$ (Ecocrop 2009). The plant flowers after 90 days and the pods mature in 140 to 210 days. The tubers are ready to be harvested at 150 to 240 days after sowing (Ecocrop, 2009).

African yam bean seeds are rich in protein $(22-25 \% \mathrm{Dm})$ and with low fibre content (crude fibre $10 \% \mathrm{Dm}$ ). The protein is particularly rich in lysine (up to $9 \%$ of protein), a value higher than that of soyabean. The percentage of the hull from the whole seed of African yam bean was 7.3\% (Agunbiade and Long, 1999). The composition of the hull of African yam bean are as followed: crude protein $11.4 \%$, crude fat $2.6 \%$, phytic acid $(8.2 \mathrm{mg} / 100 \mathrm{~g})$, potassium and minerals are the major minerals in the hull (Heuze et al., 2015). Processes such as heating, soaking or fermentation can be used to decrease antinutritional factors and improve the nutrition value of sphenostylis stenocarpa products and its by products (Onyike et al.,1995).

Considering the various attributes of African yam bean (sphenostylis stenocarpa), it would appear that appropriate utilization of this feedstuff can be used to replace soyabean meal as protein source to produce low cost diets that can be efficient in promoting the performance of starter broiler chickens and reduce demand pressure on soyabean meal as well as cost of production, hence the need to determine the growth performance of starter broiler chickens fed processed African yam bean meal as protein source in place of soyabean meal in their diets

\section{Materials and methods Experimental site}

The experiment was carried out at the poultry unit of the teaching and research farm of Michael Okpara University of Agriculture, Umudike, Umuahia, Abia State, Nigeria. The area is located on latitude $5^{0} 21^{1}$ North, longitude $7^{0} 32^{1}$ East, in the rain forest zone in Umuahia, Abia State. This site has a mean daily temperature of between $27^{\circ} \mathrm{C}-36^{\circ} \mathrm{C}$ and minimum of $20^{\circ}$ $26^{\circ} \mathrm{C}$ with relative humidity between $57 \%$ and 91\% (Eburuaja, 2010) and annual rainfall of $200 \mathrm{~mm}$ per annum and an attitude of $122 \mathrm{~m}$ above sea level. It is therefore, a humid tropical environment with temperature and relative humidity that are significant for agricultural production (Eburuaja, 2010).

\section{Procurement offeed ingredients}

African yam bean seeds (Sphenostylis stenocarpa) were procured at Ndioro market in Abia State, while other feed ingredients like maize, soyabean meal, 


\section{Anyaegbu, Onunkwo, Ezike, Ogbonna. and Amanze}

palm kernel cake, spent grain, blood meal, methionine, lysine and bone meal were bought from Jocan livestock services in Umuahia.

\section{Sorting and Processing of Test Ingredients}

The African yam bean seeds were sorted to remove stones and dirts by sieving. The seeds were soaked in water for 24 hours and then the water was removed and the seed air dried for 3 days. The seeds were toasted for 35 minutes in a frying pan, milled using hammer mill to obtain African yam bean meal (AYBM) and stored in bags for use.

Proximate analysis of the test ingredient All the processed feed ingredients, processed African yam bean meal, palm kernel cake, Brewer' dried grains, blood meal, fish meal, were subjected to proximate analysis according to AOAC (1995) to determine their nutrients composition and gross energy. All analysis was based on $100 \%$ dry matter.

The proximate analysis of the processed ingredients was done so as to use the values obtained to determine the nutrient composition of the experimental diets which were formulated from them. The components that were determined include
Dry Matter (DM), Crude Protein (CP), Ether Extract (EE) and Nitrogen Extract (NFE). The test materials fresh and processed African yam bean seed meal (AYBM) were analyzed for anti-nutrients contents such as oxalate, tannins, saponin, trypsin inhibitors, hydrogen cyanide and phytate.

\section{Experimental design}

The design of the study was completely Randomized Design (CRD). The statistical model was

$\begin{array}{lll}\text { Yij } & =\mu+\text { Ti+eji } \\ \text { Where } & & \\ \text { Yij } & = & \text { Individual observation } \\ \mu & = & \text { Population mean } \\ \mathrm{Ti} & = & \text { Treatment effect } \\ \mathrm{eij} & = & \text { Error effect. }\end{array}$

\section{Experimental starter broiler chicken diet}

Five experimental starter broiler chickens diets were formulated for the starter phase of the feeding trial. The control diet had $30 \%$ soyabean meal as major source of protein while diets 2, 3, 4 and 5 had processed African Yam bean meal (AYBM) at $10 \%, 15 \%, 20 \%$ and $25 \%$ to replace soyabean meal, respectively. Other feed ingredients remained the same in the diets (Table 1).

Table 1: Percentage an d nutrient composition of starter broiler diet containing different levels of processed African Yam Bean Meal (AYBM)

\begin{tabular}{|c|c|c|c|c|c|}
\hline Ingredients (\%) & $\begin{array}{l}\text { Diet } 1 \\
\text { (control) }\end{array}$ & $\begin{array}{l}\text { Diets } 2 \\
(10 \% \text { AYBM) }\end{array}$ & $\begin{array}{l}\text { Diet } 3 \\
\text { (15\% AYBM) }\end{array}$ & $\begin{array}{l}\text { Diet } 4 \\
(20 \% \text { AYBM })\end{array}$ & $\begin{array}{l}\text { Diet } 5 \\
(25 \% \text { AYBM })\end{array}$ \\
\hline Maize & 58.00 & 58.00 & 58.00 & 58.00 & 58.00 \\
\hline Soyabean meal & 30.00 & 27.00 & 25.50 & 24.00 & 22.50 \\
\hline AYBM* & - & 3.00 & 4.50 & 6.00 & 7.5 \\
\hline Palm kernel cake & 2.30 & 2.30 & 2.30 & 2.30 & 2.30 \\
\hline Brewers' dried grain & 2.00 & 2.00 & 2.00 & 2.00 & 2.00 \\
\hline Fishmeal & 2.00 & 2.00 & 2.00 & 2.00 & 2.00 \\
\hline Bonemeal & 3.00 & 3.00 & 3.00 & 3.00 & 3.00 \\
\hline Vit/mineral premix $* *$ & 0.25 & 0.25 & 0.25 & 0.25 & 0.25 \\
\hline L-methionine & 0.10 & 0.10 & 0.10 & 0.10 & 0.10 \\
\hline L-lysine & 0.10 & 0.10 & 0.10 & 0.10 & 0.10 \\
\hline Common salt & 0.25 & 0.25 & 0.25 & 0.25 & 0.25 \\
\hline Total & 100.00 & 100.00 & 100.00 & 100.00 & 100.00 \\
\hline Crude protein $(\%)$ & 23.00 & 23.20 & 22.92 & 22.64 & 22.37 \\
\hline $\mathrm{ME} . \mathrm{Kcal} / \mathrm{kg}$ & 2867.36 & 2897.69 & 2913.16 & 3027.05 & 3043.79 \\
\hline
\end{tabular}




\section{Growth performance of starter broiler chickens}

\section{Experimental animals and management}

One hundred and fifty, one day old Anak broiler chicks (Fidan broilers) were bought from Ibadan. They were brooded together for one week with commercial broiler starter feed (top broiler starter feed) before randomly distributing them into five treatment groups. Each treatment group contained 30 broiler chicks. Each treatment group was further subdivided into three replicates of 10 broiler chicks each. Each replicate was covered with black polythene sheets for conservation of heat. Heat was supplied by electricity and kerosene lantern during the brooding period. The floor of the pens was covered with wood shavings. Each treatment group was randomly assigned to an experimental starter broiler diet in a completely randomized design (CRD) and fed for four weeks. Feed was supplied in feed troughs build in such a way as to minimize wasting of feed. Water and feed were supplied ad-libitum. Feeding was done once daily around 8am. The birds were weighed at the beginning of the feeding trial and weekly thereafter. Feed intake was recorded daily by weighing the quantity of feed offered and the leftover the following morning. The starter phase of the feeding trial lasted 4 weeks.

\section{Data collection}

Parameters determined were initial live weight, final live weight, body weight gain, feed intake, feed conversion ratio and proximate composition of processed African yam bean meal.

\section{Data analysis}

The data collected was subjected to oneway analysis of variance (ANOVA) according to Snedecor and Cochran (1989). Where significant treatment effect was detected from the ANOVA, means were separated using Duncan's New Multiple Range Test (Steel and Torrie, 1980).

\section{Results}

Anti-nutrients composition of African Yam Bean Meal (AYBM). Data on the antinutrient composition of raw and processed African Yam Bean Meal was shown in (Table 2). There were significant differences $(\mathrm{P}<0.05)$ in the anti-nutrients composition of raw and processed African Yam Bean meal. Soaking and toasting reduced the anti-nutrients in the African Yam Bean Meal (AYBM).

Table 2: Anti-nutrient composition of raw and processed African Yam Bean Meal

\begin{tabular}{llll}
\hline Parameters & Raw $($ AYBM) & Processed AYBM & SEM \\
\hline Oxalate $(\mathrm{mg} / \mathrm{kg})$ & $8.01^{\mathrm{a}}$ & $3.12^{\mathrm{b}}$ & 1.73 \\
Hydrogen cyanide $(\mathrm{mg} / \mathrm{kg})$ & $224.02^{\mathrm{a}}$ & $48.06^{\mathrm{b}}$ & 62.40 \\
Tannins $(\mathrm{mg} / 100 \mathrm{~g})$ & $18.06^{\mathrm{a}}$ & $3.34^{\mathrm{b}}$ & 5.23 \\
Phytate $(\mathrm{mg} / 100 \mathrm{~g})$ & $428.90^{\mathrm{a}}$ & $120.11^{\mathrm{b}}$ & 109.50 \\
Trypsin inhibitor $(\mathrm{mg} / 100 \mathrm{~g})$ & $4.47^{\mathrm{a}}$ & $1.26^{\mathrm{b}}$ & 1.13 \\
\hline${ }^{\mathrm{ab}}$ means within the same row with different superscripts are significantly different $(\mathrm{P}<0.05)$ &
\end{tabular}

Table 3: Proximate composition of raw and processed African Yam Bean Meal (AYBM)

\begin{tabular}{llll}
\hline Parameters (\%) & Raw (AYBM) & Processed AYBM & SEM \\
\hline Moisture & $8.89^{\mathrm{a}}$ & $8.29^{\mathrm{a}}$ & 0.21 \\
Dry matter & $91.11^{\mathrm{a}}$ & $91.71^{\mathrm{a}}$ & 0.21 \\
Ash & $3.00^{\mathrm{a}}$ & $3.40^{\mathrm{a}}$ & 0.14 \\
Crude protein & $22.52^{\mathrm{a}}$ & $21.12^{\mathrm{a}}$ & 0.50 \\
Ether extract & $2.50^{\mathrm{a}}$ & $5.00^{\mathrm{b}}$ & 0.89 \\
Crude fibre & $3.27^{\mathrm{b}}$ & $5.73^{\mathrm{a}}$ & 0.87 \\
NFE & $59.82^{\mathrm{a}}$ & $56.46^{\mathrm{a}}$ & 1.19 \\
\hline
\end{tabular}

${ }^{\mathrm{ab}}$ mean within the same row with different superscripts are significantly different $(\mathrm{P}<0.05)$ 


\section{Anyaegbu, Onunkwo, Ezike, Ogbonna. and Amanze}

Data on proximate composition of raw and processed African yam bean meal is shown in (Table 3) above. There were no significant $(\mathrm{P}>0.05)$ differences in crude protein, moisture, dry matter and ash content of the two samples but their crude fibre content, ether extract, nitrogen free extract differ significantly $(\mathrm{P}<0.05)$ with processed African yam bean meal containing higher quantities.

Table 4: Proximate composition of experimental starter broiler chickens diets

\begin{tabular}{lllllll}
\hline Parameters & $\begin{array}{l}\text { Diets } \\
\text { (control } \\
\text { diet) }\end{array}$ & $\begin{array}{l}\text { Diet 2 10\% } \\
\text { AYBM }\end{array}$ & $\begin{array}{l}\text { Diet 3 15\% } \\
\text { AYBM }\end{array}$ & $\begin{array}{l}\text { Diet 4 20\% } \\
\text { AYBM }\end{array}$ & $\begin{array}{l}\text { Diet 5 25\% } \\
\text { AYBM }\end{array}$ & SEM \\
\hline Dry matter (\%) & 88.85 & 88.45 & 88.80 & 88.65 & 88.25 & 0.08 \\
Moisture (\%) & 11.35 & 11.55 & 11.20 & 11.35 & 11.75 & 0.08 \\
Ash (\%) & 9.05 & 11.99 & 9.24 & 8.15 & 8.10 & 0.63 \\
Crude protein (\%) & 22.80 & 22.75 & 21.00 & 21.60 & 19.95 & 1.18 \\
Ether extract (\%) & 1.67 & 1.72 & 1.74 & 1.69 & 1.63 & 0.02 \\
Crude fibre (\%) & 3.45 & 4.35 & 4.70 & 4.55 & 5.20 & 0.25 \\
NFE (\%) & 48.23 & 47.64 & 53.87 & 54.66 & 53.37 & 1.33 \\
\hline
\end{tabular}

Performance of experimental starter broilers fed processed African Yam Bean Meal (AYBM)

\section{Feed intake}

There were significant differences $(\mathrm{P}<0.05)$ among the starter broiler groups in their feed intake. The starter broilers on the control diet and 10\% African Yam Bean Meal (diet 2) recorded higher and similar feed intake which were significantly $(\mathrm{P}<0.05)$ different from other groups. The feed intake of the groups on $15 \%$ AYBM (diet 3) were similar and significantly lower than the other groups. The reason for this could be due to the higher level of some anti-nutritional factors and higher fibre content.

\section{Body weight gain}

There were significant differences $(\mathrm{P}<0.05)$ among the starter broiler groups in their body weight gain. The starter broilers on the control diet and 10\% AYBM (diet 2) recorded similar body weight gain which were significantly $(\mathrm{P}<0.05)$ higher than others. The starter broilers on $20 \%$ and $25 \%$ processed AYBM recorded similar body weight gain which were significantly $(\mathrm{p}<0.05)$ lower than others. This could be due to higher levels processed AYBM in their diets.

Table 5: Effects of experimental diets on the performance of starter broilers

\begin{tabular}{lllllll}
\hline Parameters & $\begin{array}{l}\text { Diets 1 } \\
\text { (control) }\end{array}$ & $\begin{array}{l}\text { Diet 2 } \\
\mathbf{1 0 \%} \\
\text { AYBM }\end{array}$ & $\begin{array}{l}\text { Diet 3 } \\
\mathbf{1 5 \%} \\
\text { AYBM }\end{array}$ & $\begin{array}{l}\text { Diet 4 20\% } \\
\text { AYBM }\end{array}$ & $\begin{array}{l}\text { Diet 5 } \\
\mathbf{2 5 \%} \\
\text { AYBM }\end{array}$ & $\begin{array}{l}\text { SEM } \\
\text { Initial body wt (g) }\end{array}$ \\
Final body wt (g) & 55.00 & 49.44 & 51.11 & 48.89 & 50.00 & 0.97 \\
Body wt gain (g) & 695.24 & 671.43 & 495.24 & 490.47 & 485.70 & 42.33 \\
Daily body wt gain (g) & $640.14^{\mathrm{a}}$ & $621.43^{\mathrm{a}}$ & $444.14^{\mathrm{b}}$ & $441.58^{\mathrm{c}}$ & $435.70^{\mathrm{c}}$ & 41.72 \\
Daily feed intake (g) & $22.86^{\mathrm{a}}$ & $22.19^{\mathrm{a}}$ & $15.86^{\mathrm{b}}$ & $15.77^{\mathrm{c}}$ & $15.56^{\mathrm{c}}$ & 1.49 \\
Feed conversion ratio & $86.25^{\mathrm{a}}$ & $83.25^{\mathrm{a}}$ & $61.75^{\mathrm{b}}$ & $62.50^{\mathrm{b}}$ & $63.00^{\mathrm{a}}$ & 4.94 \\
Mortality & $3.77^{\mathrm{a}}$ & $3.75^{\mathrm{a}}$ & $3.89^{\mathrm{b}}$ & $3.96^{\mathrm{b}}$ & $4.05^{\mathrm{c}}$ & 0.05 \\
\hline abc & 1 & 1 & 1 & - & - & 0.14 \\
\hline means within the same row with different superscripts are significantly different $(\mathrm{P}<0.05)$ & & & &
\end{tabular}

\section{Feed conversion ratio}

There were significant differences $(p<0.05)$ among the starter broiler groups in their feed conversion ratio. The starter broilers on the control diet and diet 2(10\% AYBM) recorded significantly $(\mathrm{p}<0.05)$ superior feed conversion ratio more than other groups. This illustrated better conversion of African Yam Bean Meal based diets into meat. The poorest feed conversion ratio of 4.05 of those on diets 5 (25\% AYBM) showed poor utilization of the diet. 


\section{Growth performance of starter broiler chickens}

Table 6: Economics of starter broilers fed processed AYBM in their diets

\begin{tabular}{|c|c|c|c|c|c|c|}
\hline Parameters & $\begin{array}{l}\text { Diet } 1 \\
\text { (control) }\end{array}$ & $\begin{array}{l}\text { Diet } 2 \\
10 \% \\
\text { AYBM }\end{array}$ & $\begin{array}{l}\text { Diet } 2 \\
15 \% \\
\text { AYBM }\end{array}$ & $\begin{array}{l}\text { Diet } 2 \\
20 \% \\
\text { AYBM }\end{array}$ & $\begin{array}{l}\text { Diet } 2 \\
25 \% \\
\text { AYBM }\end{array}$ & SEM \\
\hline Cost/kg feed ( $)$ & $125.10^{\mathrm{c}}$ & $123.57^{b}$ & $122.81^{b}$ & $122.04^{\mathrm{ab}}$ & $121.28^{\mathrm{a}}$ & 0.58 \\
\hline Cost of prod./kg broiler & $471.63^{\mathrm{ab}}$ & $463.38^{\mathrm{a}}$ & $477.73^{b}$ & $483.28^{\mathrm{b}}$ & $491.18^{c}$ & 4.25 \\
\hline
\end{tabular}

In the starter broiler trial, significant differences $(p<0.05)$ existed in their cost of feed per $\mathrm{kg}$. The cost per $\mathrm{kg}$ of feed was cheapest for diet 5 (25\% AYBM), while the costliest was the control diet. Diet $2(10 \%$ AYBM) appeared to be the most economical to use in feeding starter broilers. The cost of production of $1 \mathrm{~kg}$ broiler was lowest for diet 2 (10\% AYBM) N463.38 against N471.63 for these on control diet.

\section{Discussion \\ Anti-nutrient composition of raw and processed African Yam Bean Meal}

The result obtained in respect to the antinutrients of both raw and processed African Yam Bean Meal showed that the trypsin inhibitor of raw and African yam bean seed was $4.47 \mathrm{mg} / 100 \mathrm{~g}$ but it was reduced in processed meal to $1.26 \mathrm{mg} / 100 \mathrm{~g}$. This agrees with the fact that trypsin inhibitors are heat labile and that the use of heat treatment can readily inactivate them (Liener, 1980; Akanji, et al., 2003; Akinmutimi, 2004). The value of tannin in the seed ranged from $18.06 \mathrm{mg} / 100 \mathrm{~g}$ in raw seed to $3.3 \mathrm{mg} / 100 \mathrm{~g}$ in processed seed of African yam bean meal. Soaking and toasting as processing technique brought a reduction in the quantity of tannin in the processed seeds. This confirms the thermostability of tannin (D'mello and Devendra, 1995; Okwu, 2002). Poor detoxification of tannins by boiling and toasting has been reported (Akinmutimi, 2004; Ewa, 1999; Izundu, 1999). This could be due to inability of the method to hydrolyse the intra-molecular forces that exist within tannin (Akinmutimi, 2004). He also reported that the use of seed containing tannins could result in formation of complex linkage with protein by tannins leading to loss of protein and consequent poor growth. The concentration of hydrocyanic acid in the raw seed was significantly higher $(\mathrm{p}<0.05)$ than that in the processed seed. There was high reduction in hydrocyanic acid from $224.04 \mathrm{mg} / \mathrm{kg}$ to $48.06 \mathrm{mg} / \mathrm{g}$. This may be due to the volatile nature of $\mathrm{HCN}$ (Oke et al., 1996) and its boiling point (Montgomery, 1995). There were no significant differences $(p>0.05)$ in the value of phytic acid obtained for both raw and processed African yam bean meal. There was low reduction of phytic acid by soaking and toasting. Phytic acid is heat stable (Oke, et al., 1996). Usage of seeds containing high percentage of phytic acid may result in formation of insoluble salt with minerals like calcium and magnesium making them unavailable for metabolic processes (Roberts, et al., 2006). Ene-obong (1992) reported that African yam bean seed has lesser phytic acid than pigeon pea (8.31$11.31 \mathrm{mg})$ and cowpea $(7.29-9.92 \mathrm{mg} / \mathrm{g})$.

\section{Performance of starter broilers fed AYBM in their diets}

The starter broilers on the control diet and $10 \%$ processed African yam meal diet recorded higher and similar feed intake which were significantly different $(\mathrm{p}<0.05)$ from other groups. The feed intake of the groups on soaking and toasted $15 \%$ AYBM, $20 \%$ AYBM and 25\% AYBM diets were similar and significantly $(\mathrm{p}<0.05)$ lower than other groups. This agreed with the 
report of (Ojewola, et al., 2006) who observed that toasting is not very efficient in detoxifying grain legumes. The residual anti-nutritional factors such as saponin, tannin and phytate cause irritation of the lining of the mouth and gut (Olomu, 1995) and hence reduction in palatability and utilization. The low feed intake in turn resulted in low body weight gain. The lower weight gain of starter broilers fed diets containing soaked and toasted AYBM agreed with the work of (Ojewola, et al., 2006) who reported depressed weight gain when toasted AYBM were fed to broiler chicken.

They attributed this to appropriate characterization of AYBM carbohydrate and protein and to the presence of antinutritional factors. Anti-nutritional factors such as trypsin inhibitors have been known to depress weight gain because they bind irreversibly to protein enzymes making them unavailable for their function. These were significant differences $(p<0.05)$ in the feed conversion ratio of the starter broiler groups, but numerically, those on control diet 1 and diet $2(10 \%$ AYBM) diets were better.

\section{Conclusion}

The trials herein reported have shown that soaking and toasting of African yam bean will not more effective for eliminating the anti-nutrient content because there were still traces of anti-nutrients in soaked and toasted AYBM as shown by the result of anti-nutrient determination.

The result showed that processed African yam bean meal could not be used to completely replace soyabean meal in starter broiler diets and for optimal performance of starter broilers, only up to $10 \%$ of soyabean meal in the diet could be replaced with processed African yam bean meal without affecting feed intake, growth rate and feed conversion ratio.

\section{References}

Food and Agricultural Organization 1982. Metabolizable energy predicated by the equation proposed by FAO in the book, Tropical feeds.

Oyenuga, V. A. 1997. Nigeria food and feeding stuffs. Ibadan University Press, Nigeria.

Adejinmi, O. O., Adejinmo, J. O. and Adeleya, I. O. A. 2000 . Replacement values of fish meal with soldier fly larvae meal in broiler diets. Nigerian Poultry Science Journal, (1): 52-60.

Oyinmonyi, A. E. and Okeke, G. C. 2005. Carcass organ and pathological characteristics of grower pigs fed cassava peel meal. J. Agric. Food Environ. Ext., 1: 1-4.

Aduku, A. O. and Olukosi, J. O. 1991. Rabbit management in the tropics, production, processing, utilization, marketing economics, practical training, research and future prospects. G.U. Publications, Abuja,pp. 33-75.

Akinmutimi, A. H., Amaechi, N., and Unogu, M. 2006. Evaluation of Raw African Bean as Substitute for Soyabean in the Diet of Weaner Rabbits. Journal of Animal Vet. Advances, 5(11): 907-911.

Alegbeleye, S. O. 2002. Evaluation of African Yam Bean (Sphenostylis stenocarpa) hotchst ex a rich) as a replacement for soyabean in the diets of Nile tilapia (Oreochromis niloticus) fingerlings. Asset Services Agriculture and Environment, 2(2): 73-79.

Ecocrop, 2009. Ecocrop database. FAO. Heuze, V., Tran. G. 2016: African yam bean (Sphenostylis stenocarpa), Feedipedia, a 


\section{Growth performance of starter broiler chickens}

programme by INRA CIRAD, A F Z a n d F A O. http://www.feedipedia.org/node/7 04 last updated on March 16, 2016, 11:56.

Agunbiade, S. O. and Longe, O. G. 1999. Essential amino acid composition and biological quality of Bean AYB (Hoch rich) harms 43(1): 2224.

Heuze, V. V., Tran, G., Archimede, H., Regner, C., Bastianelli, D., and Lebas, F. 2015. Cassava roots, feedipedia, a programme by INRA (IRAD, AFZ and FAO) http://www/feedipedia.org/node/5 27

Onyeike, E. N., Ayalogu, E. O., Uzogara, S. G. 1995. Influence of heat procession of African Yam Bean Seed (Sphenostylis stenocarpa) Flour on the Growth and Organ Weight of Rats. Plant Foods Hum. Nutr., 49: 85-93.

Eburuaja, A. S. 2010. Chemical and nutrition evaluation of African yam bean as an alternative protein source in broiler diets. Ph.D Thesis, Michael Okpara University of Agriculture, Umudike.

A. O. A. C. 1995. Official methods of official and analytical chemist. Washington DC.

Snedecor, G. W. and Cochran, W. G. 1989. Statistical methods $8^{\text {th }}$ edition Ames: IOWA State University Press.

Steel, R. D. G. and Torrie, J. H. 1980. Principal and procedures of statistics: A biometrical approach $2^{\text {nd }}$ edition, pp. 623.

Nwokolo, E. A. 1996. The need to increase the consumption of pulse in the developinf world. Food and feed from legumes and oil seeds.
Chapman and Hall, London. Pp. 311.

Oluyemi, J. A. and Robert, F. A. 2000. Poultry production in warm wet climates ( $2^{\text {nd }} E d$.) Macmillan Press Ltd. London. Pp. 195-199.

Liener, J. E. 1962. Toxic factors in edible legumes and their elimination. Anim. J. Clin. Nutri., 11:281-284.

Akanji, A. M., Ologbobo, A. D., Emiola, I. A. and Adedeji, O. S. 2003. The effect of various processing on haemaglutinin and other antinutritional factors in Jackbean. NSAP Proceeding, IARST, Ibadan. Pp. 189-193.

Akinmutimi, A. H. 2004. Evaluation of swordbean (Canavalca gladiata) as an alternative feed resources for broiler chicks. Ph.D Thesis. College of Animal Science and Animal Health, Michael Okpara University of Agriculture, Umudike. Pp. 4-17.

D'mello, J. P. and Devendra, F. 1995. Tropical Legumes in Animal Nutrition. United Kingdom. Pp. 96133.

Ewa, U. E. 1999. Evaluation of the metabolizable energy and true digestive protein of jackbean (Canavalia ensiformis). B.Sc. Thesis. Michael Okpara University of Agriculture, Umudike. Pp. 2533.

Okwu, N. D. E. 2002. The effect of cooked Mucuna utilis as a substitute for soyabean meal in broiler finisher diet. B.Sc. Project, Michael Okpara University of Agriculture, Umudike. Pp. 1-5.

Oke, D. B., Fetuga, B. L. A. and Tewe, O. O. 1996. Effect of autoclaving on anti-nutritional factors of cowpea varieties. Nigerian Journal of Animal Production, 23(1): 33-38. 
Montgomery, R. D. 1995. Observation on the cyanide content and toxicity of tropical pulses. W. India Med., 3(13): 1-11.

Izundu, R. O. 1999. Effect of processing on energy and protein digestibility of swordbean (Canavalia gladista) using Muscovy duck (Carina mushata). B.Sc. Project, Michael Okpara Okpara University of Agriculture, Umudike. Pp. 1-25.

Ene-obong, H. N. 1992. Nutritional evaluation, consumption pattern and processing of the African yam bean (Sphenostylis stenocarpa) Ph.D Thesis, Department of Home Science and Nutrition, University of Nigeria, Nsukka, Enugu State.

Roberts, K. M., Daryl, K. G., Peter, A. M. and Victor, W. R. 2006. Harpes illustrates biochemistry, $27^{\text {th }}$ Edition. McGraw Hill, New York. 27: 489-506.
Emenalom, O. O., Chima, M. C., Etuk, E. B. and Esonu, B. O. 2007. Comparative evaluation of processed velvet bean (Mucuna pruriene), soyabean and groundnut meals on the performance and internal organ characterictics of broilers. Proceeding of the $32^{\text {nd }}$ Annual Conf. Nigeria Soc. Animal Production, pp. 220-222.

Received: $10^{\text {th }}$ September, 2018 Accepted: $21^{s t}$ December, 2018 